\title{
Gene $\times$ Abstinence Effects on Drug Cue Reactivity in Addiction: Multimodal Evidence
}

\author{
Scott J. Moeller, ${ }^{1}$ Muhammad A. Parvaz, ${ }^{1}$ Elena Shumay, ${ }^{2}$ Nicasia Beebe-Wang, ${ }^{1}$ Anna B. Konova, ${ }^{1,3}$ Nelly Alia-Klein, ${ }^{1}$ \\ Nora D. Volkow, ${ }^{4,5}$ and Rita Z. Goldstein ${ }^{1}$ \\ ${ }^{1}$ Departments of Psychiatry and Neuroscience, Icahn School of Medicine at Mount Sinai, New York, New York 10029, ${ }^{2}$ Medical Department, Brookhaven \\ National Laboratory, Upton, New York 11973, ${ }^{3}$ Department of Psychology, Stony Brook University, Stony Brook, New York 11794, ${ }^{4}$ National Institute on \\ Drug Abuse, Bethesda, Maryland 20892, and ${ }^{5}$ National Institute on Alcohol Abuse and Alcoholism, Bethesda, Maryland 20892
}

Functional polymorphisms in the dopamine transporter gene (DAT1 or SLC6A3) modulate responsiveness to salient stimuli, such that carriers of one 9R-allele of DAT1 (compared with homozygote carriers of the 10R-allele) show heightened reactivity to drug-related reinforcement in addiction. Here, using multimodal neuroimaging and behavioral dependent variables in 73 human cocaine-addicted individuals and 47 healthy controls, we hypothesized and found that cocaine-addicted carriers of a 9R-allele exhibited higher responses to drug cues, but only among individuals who had used cocaine within $72 \mathrm{~h}$ of the study as verified by positive cocaine urine screens (a state characterized by intense craving). Importantly, this responsiveness to drug cues was reliably preserved across multimodal imaging and behavioral probes: psychophysiological event-related potentials, self-report, simulated cocaine choice, and fMRI. Because drug cues contribute to relapse, our results identify the DAT1R 9R-allele as a vulnerability allele for relapse especially during early abstinence (e.g., detoxification).

\section{Introduction}

The corticobasal ganglia reward circuit, which comprises the ventral striatum and main cortical and subcortical input regions, including the orbitofrontal cortex (OFC), anterior cingulate cortex, and midbrain, is a central hub that mediates the execution of motivated behaviors (Haber and Knutson, 2010). This reward circuit relies heavily on dopamine (DA) neurotransmission, which has core roles in reward prediction (Schultz, 2010), incentive salience (Berridge, 2007), and arousal (Horvitz, 2000), among others. Such DA neurotransmission and consequent responsiveness to salient stimuli are further modulated by functional polymorphisms (i.e., sequence variations) in dopaminergic genes. For example, a polymorphism in the 3 '-UTR of the DA transporter gene (DAT1 or SLC6A3) that produces common alleles with 9-repeats (9R) and 10-repeats (10R) has been linked to DA transporter density in the dorsal and ventral striatum (higher density in 9R-allele carriers) (Shumay et al., 2011). Furthermore, the length of the polymorphic region was associated with phasic DA release, wherein carriers of one 9R-allele have lower tonic but higher phasic DA levels than homozygous carriers of the 10R-allele (van Dyck et al., 2005).

\footnotetext{
Received Feb. 14, 2013; revised April 25, 2013; accepted May 8, 2013.

Author contributions: S.J.M., M.A.P., E.S., N.A.-K., N.D.V., and R.Z.G. designed research; A.B.K. performed research; M.A.P. and E.S. contributed unpublished reagents/analytic tools; S.J.M., M.A.P., E.S., N.B.-W., and A.B.K. analyzed data; S.J.M., N.B.-W., A.B.K., N.D.V., and R.Z.G. wrote the paper.

This work was supported by National Institute on Drug Abuse Grant 1R01DA023579 to R.Z.G., Grant 1F32DA030017-01 to S.J.M., and Grant 1F32DA033088 to M.A.P. We thank Michail Misyrlis, Thomas Maloney, Patricia A. Woicik, Dardo Tomasi, Ruiliang Wang, and Gene-Jack Wang for assistance.

The authors declare no competing financial interests.

Correspondence should be addressed to Dr. Rita Z. Goldstein, One Gustave L. Levy Place, Box 1230, New York, NY 10029-6574. E-mail: rita.goldstein@mssm.edu.

DOI:10.1523/JNEUROSCI.0695-13.2013

Copyright $\odot 2013$ the authors $\quad 0270-6474 / 13 / 3310027-10 \$ 15.00 / 0$
}

Importantly, prior studies have suggested that this DAT1 9Rallele may confer vulnerability for sensitivity to drug cues in addiction. In cigarette smokers, for example, DAT1 9R-allele carriers (compared with smokers homozygous for the 10R-repeat allele) reported stronger craving when exposed to smoking cues (Erblich et al., 2005) or stress (Erblich et al., 2004); 9R-allele smokers also showed more smoking-induced DA release in the caudate and nucleus accumbens as measured with positron emission tomography (Brody et al., 2006), and more responsiveness to smoking-related cues in corticolimbic regions, including the OFC as measured with perfusion fMRI (Franklin et al., 2011), effects that have been correlated with subjective craving (Franklin et al., 2011) and/or attention bias to the drug cues (Wetherill et al., 2012). Together, current evidence raises the intriguing hypothesis that the lower tonic yet increased phasic DA neurotransmission conferred by the DAT1 9R-allele augments response to drug-related cues, an association perhaps further modulated by drug-relevant state variables (e.g., craving).

The current study tested whether drug cue reactivity is modulated by DAT1 in combination with another highly important drug-relevant state variable: recent cocaine use. Recent cocaine use was objectively operationalized as the presence of cocaine metabolites in urine, a variable that modulates response to reinforcement (including to cocaine cues) (Moeller et al., 2010; Parvaz et al., 2012) and predicts treatment outcome (Poling et al., 2007; Ahmadi et al., 2009; García-Fernández et al., 2011). As part of a multimodal imaging and behavioral design, individuals with cocaine use disorder (CUD) and healthy controls were exposed to cocaine- and noncocaine stimuli, during which we measured event-related potentials (ERPs), self-reported valence and arousal ratings, simulated cocaine choice, and fMRI responsive- 
ness. We hypothesized that CUD carriers of a 9R-allele, especially those with positive cocaine urine screens, would show heightened responsiveness to cocaine stimuli.

\section{Materials and Methods Subjects}

Seventy-three CUD (63 males) and 47 healthy controls (41 males) participated in this research, recruited through advertisements, local treatment facilities, and word of mouth; all provided written informed consent in accordance with the local Institutional Review Board. Exclusion criteria were as follows: (1) head trauma (with a loss of consciousness $>30 \mathrm{~min}$ ); (2) any psychiatric, medical, or neurological disorder requiring hospitalization or regular monitoring (except for substance abuse disorders and highly comorbid disorders, such as depression and post-traumatic stress disorder); (3) current use (within the last 6 months) of psychoactive medications; (4) in the healthy controls, current or past history of substance use disorder (other than nicotine) or any other psychiatric illness; and (5) positive urine screens for drugs of abuse other than cocaine (avoiding possible interference of other drugs when interpreting results, such as the use of benzodiazepines to assuage withdrawal symptoms). These subjects underwent a comprehensive diagnostic interview, which consisted of the following: (1) structured clinical interview for DSM-IV axis I disorders (First et al., 1996); (2) Addiction Severity Index (McLellan et al., 1992), a semistructured interview instrument used to assess history and severity of substance-related problems in seven problem areas (medical, employment, legal, alcohol, other drug use, family-social functioning, and psychological status); (3) Cocaine Selective Severity Assessment Scale (Kampman et al., 1998), measuring cocaine abstinence/withdrawal signs and symptoms (i.e., sleep impairment, anxiety, energy levels, craving, and depressive symptoms) $24 \mathrm{~h}$ within the time of interview; (4) Severity of Dependence Scale (Gossop et al., 1992); and (5) Cocaine Craving Questionnaire (Tiffany et al., 1993). This interview identified the following cocaine-related diagnoses in CUD: current cocaine dependence $(N=52)$, cocaine dependence in partial remission $(N=11)$, and cocaine dependence in full remission $(N=10)$. Current axis I comorbidities were identified in nine CUD subjects, including marijuana use disorders $(N=3)$, alcohol use disorders $(N=6)$, ecstasy abuse $(N=1)$, opiate (heroin) dependence $(N=2)$, major depressive disorder $(N=1)$, and post-traumatic stress disorder $(N=3)$. Fifty subjects reported past comorbidities, including marijuana use disorders $(N=33)$, alcohol use disorders $(N=30)$, stimulant abuse $(N=1)$, opiate dependence $(N=3)$, phencyclidine use disorders $(N=$ $2)$, major depressive disorder $(N=8)$, and post-traumatic stress disorder $(N=3)$.

\section{Genetics screening}

Using DNA extracted from the peripheral blood, all subjects were genotyped by PCR as previously described (Shumay et al., 2011) for the 3'UTR VNTR of the SLC6A3. Because cocaine blocks the DA transporter and because of the known deficits in DA functioning in CUD (Volkow et al., 2011), this population is appropriate and important for investigating the effects of DAT1 polymorphisms (although we accordingly focused on $D A T 1$, two other dopaminergic genes were also examined as described in the Control analyses section). From these genetic analyses, and consistent with recent neuroimaging studies in addiction (Franklin et al., 2011; Wetherill et al., 2012), subjects were partitioned into those who were homozygous carriers of the 10R-allele $(10 \mathrm{R} / 10 \mathrm{R}$ genotype, $N=70)$ and those who were carriers of at least one 9R-allele (encompassing 9R/10R and 9R/9R genotypes, $N=50$ ). Observed frequency of the major DAT1 genotypes were close to expected according to Hardy-Weinberg assumptions $\left[\chi^{2}(1)=0.38\right.$, not significant $]$.

\section{Cocaine urine status}

The presence of cocaine metabolites in urine was ascertained with a triage urine panel for abused drugs (Biopsych) in all subjects on study day. Our prior studies have similarly used this cocaine urine status variable (positive vs negative) to subgroup CUD, with effects on neuropsychological functioning (Woicik et al., 2009), reward-associated ERPs (Parvaz et al.,
2012), and simulated drug choice (Moeller et al., 2010). Thus, although the urine grouping itself was determined post hoc, the decision to group based on this variable was firmly a priori. Results of this urine screen showed that 35 CUD tested positive for cocaine in urine $\left(\mathrm{CUD}^{+}\right)$, objectively confirming use within $72 \mathrm{~h}$ before study time; 38 CUD tested negative for cocaine in urine $\left(\mathrm{CUD}^{-}\right)$. Importantly, although $\mathrm{CUD}^{+}$ had used cocaine within $72 \mathrm{~h}$ of the study, none was acutely intoxicated upon arrival as determined by the study staff. As expected, cocaine craving was greater in $\mathrm{CUD}^{+}$than $\mathrm{CUD}^{-}$(across genotypes; independent $\left.t_{(87)}=5.57, p<0.001\right)$. Table 1 provides comprehensive information on the current study sample.

\section{Main study procedures}

Study procedures encompassed four main components, all described in detail below.

\section{ERPs}

During passive viewing of pleasant, unpleasant, neutral, and cocaine pictures [2000 ms per picture; 30 pictures per picture category; the first three categories selected from the International Affective Picture System (Lang et al., 2008), and the cocaine pictures selected from freely available online and in-house collections (Moeller et al., 2009)], scalp-recorded ERPs [specifically, the late positive potential (LPP), which is thought to index stimulus salience (Hajcak et al., 2010)] were measured by EEG. Consistent with our prior research (Moeller et al., 2012), LPPs for each picture type were defined as the average activity that appeared 400-2000 ms after stimulus onset at the $\mathrm{Cz}, \mathrm{FCz}, \mathrm{FC} 1, \mathrm{FC} 2$, and Fz electrodes; the average activity in the $200 \mathrm{~ms}$ window before picture onset served as the baseline.

Psychophysiological recordings. A 64 silver-silver chloride electrode cap was positioned according to the International 10/20 System and was used to obtain continuous EEG (Neuroscan) and electro-oculogram recordings (using a frontocentral electrode as ground). Electrodes were placed to record horizontal and vertical eye movements. The EEG was digitized at a rate of $500 \mathrm{~Hz}$ and amplified with a gain of 250, and a bandpass filter of $0-70 \mathrm{~Hz}$. The amplifiers were calibrated before each recording. Electrode impedances did not exceed $10 \mathrm{k} \Omega$ for any electrodes used in the analysis.

All bioelectric signals were analyzed off-line using Statistical Parametric Mapping (SPM8) for MEG/EEG (Wellcome Department of Cognitive Neurology, London; www.fil.ion.ucl.ac.uk/spm/) and custom MATLAB code (MathWorks). Data were filtered with low and high cutoffs of 0.01 and $30 \mathrm{~Hz}$, respectively, and were then rereferenced to the averaged electrical activity from all $64 \mathrm{scalp}$ sites. The artifact rejection procedure identified a voltage step of $>75 \mu \mathrm{V}$ between sample points and a peakto-peak voltage difference of $150 \mu \mathrm{V}$ within an epoch. Additional artifacts were identified through visual inspection and subsequently rejected. Robust averaging was also used to remove artifacts (Wager et al., 2005).

\section{Picture ratings}

Immediately after passive viewing, subjects rated each of these pictures on valence (pleasantness) and arousal from 1 to 9 (higher numbers $=$ higher pleasantness/arousal).

\section{Picture choice}

Choice to view these pictures was measured under explicit contingencies (when choice was made between two fully visible side-by-side images: explicit task) and under more probabilistic contingencies (when choice was made between pictures hidden under flipped-over cards: probabilistic task) (Moeller et al., 2009). In prior work using these choice tasks, the more CUD chose to view cocaine stimuli specifically over pleasant stimuli, the higher was the actual cocaine use as measured both concurrently (Moeller et al., 2009) and prospectively (Moeller et al., 2013).

Explicit choice task. The explicit choice task prompted subjects to choose between two simultaneously (side-by-side) presented images of different categories to be enlarged to cover the computer screen with continuous button pressing for up to $5000 \mathrm{~ms}$. If subjects failed to respond for $500 \mathrm{~ms}$, the images returned from their full-screen size to the side-by-side display. The total number of button presses for each cate- 
Table 1. Demographics and drug use/severity of all study subjects as a function of DAT1 genotype and urine status

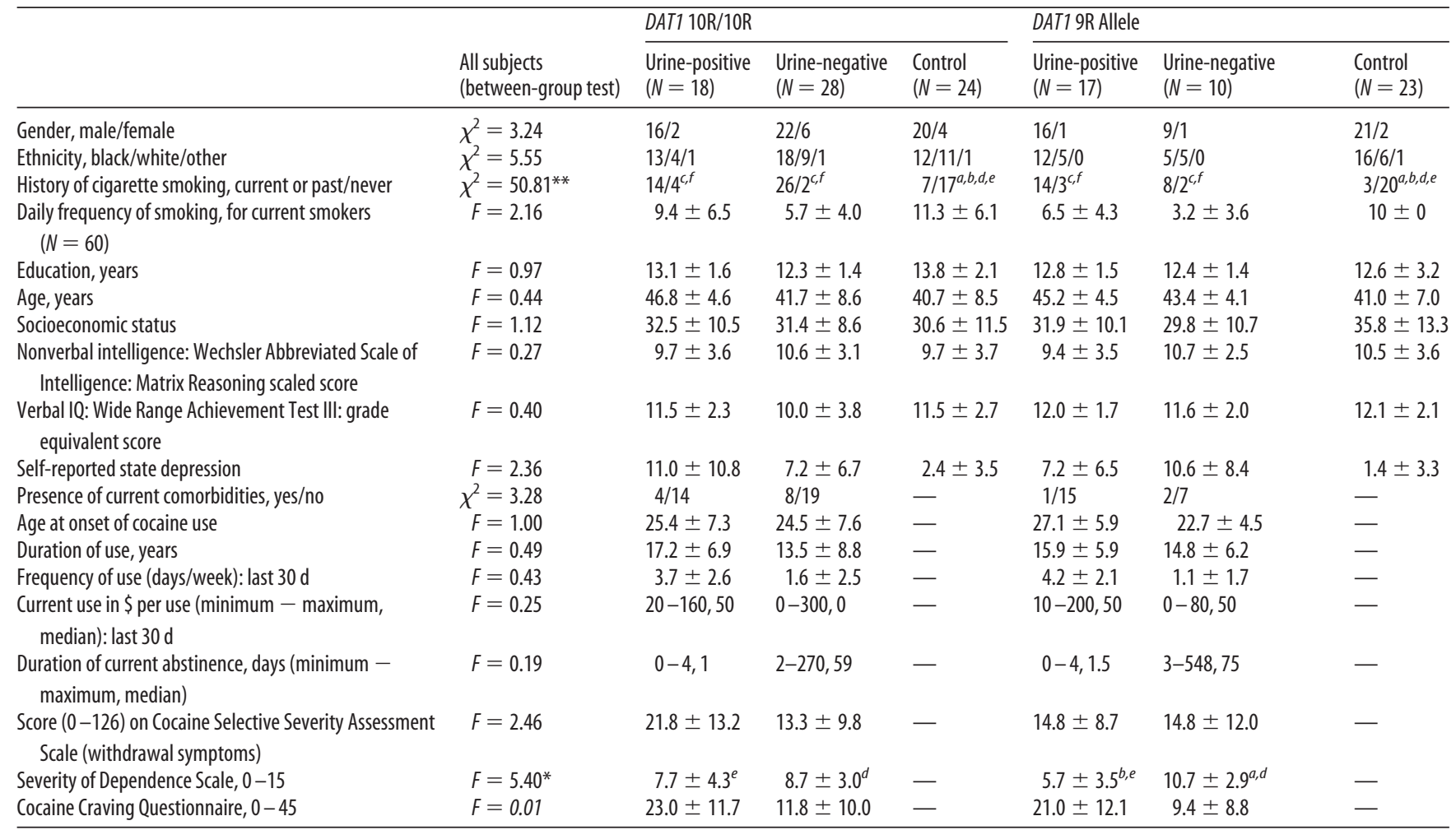

${ }^{a}$ Significantly different from urine-positive DAT1 10R/10R group.

${ }^{b}$ Significantly different from urine-negative DAT1 10R/10R group.

'Significantly different from DAT1 10R/10R control group.

${ }^{d}$ Significantly different from urine-positive DAT1 9 R allele group.

${ }^{e}$ Significantly different from urine-negative DAT1 9 R allele group.

fSignificantly different from DAT1 9R allele control group.

${ }^{*} p<0.05,{ }^{* *} p<0.001$; comorbidity data were unavailable for three cocaine subjects.

gory was summed across 70 choice trials and reflected subjects' choice and motivation (through continuous button pressing) to view images of each category.

Probabilistic choice task. The probabilistic choice task allowed subjects to demonstrate preference under less certain task contingencies than those in the explicit task. In this task, subjects were presented with four virtual and flipped-over card decks on a computer screen. Upon selection of a deck (via a single button press), an image from the selected deck covered the screen for $2000 \mathrm{~ms}$ of passive viewing. Each deck contained 26 pictures of a particular category (e.g., cocaine pictures), and four pictures of other categories (e.g., pleasant, unpleasant, neutral) intermixed within each deck for a total of 30 images in each deck. Once a subject selected a particular deck eight times, the next task repetition (run) began with a different arrangement of decks. Each subject completed four runs, and the total number of cards selected from each category was summed across the runs. The probabilistic arrangement of pictures reduced awareness of deck identity but still allowed subjects to establish a preference for certain categories of pictures.

fMRI drug word task

Subjects completed an fMRI drug word task that has been extensively described previously (e.g., Goldstein et al., 2009; Konova et al., 2012). In brief, the task consisted of eight 3.4 min task repetitions (four drug, four neutral), each containing two blocks of 20 drug or neutral words, interleaved with a $20 \mathrm{~s}$ white fixation cross overlaid on a black background. Subjects performed each word sequence under one of four counterbalanced monetary reward amounts $(50 \$, 25 \$, 1 \$$, or $0 \$)$, gained for correct performance for up to $\$ 75$ of real money (effects of money were not investigated in this study). Each word trial consisted of a $500 \mathrm{~ms}$ fixation cross, a $2000 \mathrm{~ms}$ word presentation (for word reading), a $500 \mathrm{~ms}$ response window (response was made using a Cedrus brand Lumina model LP-
400), and a $500 \mathrm{~ms}$ feedback slide (correct/incorrect). Word color order was pseudorandomized across all task runs.

Image acquisition. Scanning was performed on a $4 \mathrm{~T}$ whole-body Var$\mathrm{ian} /$ Siemens MRI scanner. BOLD responses were measured as a function of time using a T2*-weighted single-shot gradient-echo EPI sequence ( TE/TR $=20 / 1600 \mathrm{~ms}, 4 \mathrm{~mm}$ slice thickness, $1 \mathrm{~mm}$ gap, 33 coronal slices, $20 \mathrm{~cm}$ field of view, $64 \times 64$ matrix size, $90^{\circ}$ flip angle, $200 \mathrm{kHz}$ bandwidth with ramp sampling, 128 time points, and 4 dummy scans, discarded to avoid nonequilibrium effects in the fMRI signal). Anatomical images were collected using a T1-weighted 3D-MDEFT sequence (Lee et al., 1995) $(\mathrm{TE} / \mathrm{TR}=7 / 15 \mathrm{~ms}, 0.94 \times 0.94 \times 0.94 \mathrm{~mm}$ spatial resolution, 144 axial slices, 256 readout and $192 \times 96$ phase-encoding steps, $16 \mathrm{~min}$ scan time). A modified T2-weighted hyperecho image $(\mathrm{TE} / \mathrm{TR}=42$ / $10000 \mathrm{~ms}$, echo train length $=16,256 \times 256$ matrix size, 30 coronal slices, $0.86 \times 0.86 \mathrm{~mm}$ in-plane resolution, $5 \mathrm{~mm}$ slice thickness, no gap, 2 min scan time) was also acquired.

Image processing. Subsequent analyses were performed with the Statistical Parametric Mapping package (SPM8; Wellcome Department of Cognitive Neurology, London) running on MATLAB version 7.7 (MathWorks). A six-parameter rigid body transformation (3 rotations, 3 translations) was used for image realignment and to correct for head motion; $2 \mathrm{~mm}$ displacement and $2^{\circ}$ rotation in any of the axes in any of the task runs were used as criteria for acceptable motion. Spatial normalization to a standard EPI template (Montreal Neurological Institute) was performed using a 12-parameter affine transformation, resulting in a final voxel size of $3 \times 3 \times 3 \mathrm{~mm}$. An $8 \mathrm{~mm}^{3}$ full-width at half maximum Gaussian kernel was used to smooth the data. A general linear model and a box-car design convolved with a canonical hemodynamic response function and high-pass filter (cutoff frequency: 1/520 s) were used to calculate individual BOLD-fMRI maps. 


\section{Main analyses}

Because recent reviews have suggested that cocaine-induced DA levels increase the salience of cocaine rewards while simultaneously decreasing the salience of natural (nondrug) reinforcers (Goldstein and Volkow, 2011), and that comparison between competing reinforcers is important in differentiating addicted individuals from those who self-administer drugs because of a lack of other viable options (Ahmed, 2010), the primary comparison of interest for our dependent measures was between two salient picture categories for CUD: cocaine and pleasant images. To obtain these measures for each dependent measure, raw scores for pleasant variables were subtracted from raw scores for the cocaine variables, creating the cocaine $>$ pleasant contrast for LPPs, valence and arousal ratings, explicit choice, and probabilistic choice. However, given the centrality of the drug $>$ neutral comparison in the addiction literature, we also created and inspected contrasts in which raw scores for neutral variables were subtracted from raw scores for the cocaine variables. For the fMRI data, the primary contrast of interest was percentage signal change for the drug word block minus the fixation baseline for each subject (drug word $>$ baseline fixation); indeed, because there were no pleasant, nondrug-related words in the task, the drug $>$ fixation contrast represents the closest analog to the picture tasks. However, similarly to the other variables, a second contrast of interest was also inspected, reflecting percentage signal change for the drug word block minus the neutral word block for each subject (drug word $>$ neutral word). For all fMRI analyses, we inspected a priori (and independent) ROIs, all created using PickAtlas: anatomical masks in the lateral OFC [encompassing Brodmann Areas (BA) 11 and 47] and medial OFC (encompassing portions of BA 11 and the gyrus rectus that were distinct from the lateral OFC ROI), and a $10 \mathrm{~mm}$ spherical volume of interest in the ventral striatum centered at the peak coordinates from Franklin et al. (2011) as follows: $x= \pm 4, y=4$, $z=-6$. The OFC was our main ROI because this region is critical in computing subjective value, even in situations not requiring a choice (Padoa-Schioppa and Cai, 2011); importantly, this region was also shown to be modulated by DAT1 (Franklin et al., 2011). Although this latter study showed a $9 \mathrm{R}$-allele $>10 \mathrm{R} / 10 \mathrm{R}$ effect that was primarily localized to the medial OFC (Franklin et al., 2011), inspection of the cluster indicates that it also extended to more lateral portions of the OFC, justifying our approach of inspecting both OFC subregions. Also leaning on this same study (Franklin et al., 2011), we tested for a similar pattern of effects in the ventral striatum.

Statistical analyses primarily consisted of between-group 3 (diagnosis: $\mathrm{CUD}^{+}, \mathrm{CUD}^{-}$, control $) \times 2(\mathrm{DAT} 1$ genotype: $10 \mathrm{R} / 10 \mathrm{R}$ vs $9 \mathrm{R} / 10 \mathrm{R}$ or 9R/9R) ANOVAs, but we also performed correlation analyses between our dependent variables and select drug use variables (specifically, those that are relevant to abstinence/recent drug use: craving, withdrawal, and duration of cocaine abstinence). To analyze the fMRI data, the selected contrasts were entered into one-way ANOVAs in SPM8, where subjects were partitioned by diagnosis $\left(\mathrm{CUD}^{+}, \mathrm{CUD}^{-}\right.$, control) and DAT1 genotype (10R/10R vs $9 \mathrm{R} / 10 \mathrm{R}$ or $9 \mathrm{R} / 9 \mathrm{R})$. Then, for each subject, fMRI BOLD activity (drug $>$ fixation or drug $>$ neutral) in each entire ROI (lateral and medial OFC, ventral striatum) was extracted using MARSBAR and compared between the groups in SPSS. In addition to these central ROI analyses, we tested for whole-brain diagnosis $\times D A T 1$ interactions at $p<0.05$ family-wise error corrected at the voxel-level. For all statistical analyses, all subjects with available data were included. Significance was set at $p<0.05$ for all ANOVAs, and $p<0.01$ for all correlations (the latter to minimize type I error).

\section{Control analyses}

Apart from our main analyses, we also performed control analyses that were meant to bolster our main results. These control analyses proceeded in four steps.

\section{Control tasks}

To rule out potentially confounding factors, we analyzed results from two additional neuropsychological tasks of attention and inhibitory control, respectively, for which the dependent variables were unspecific to the subjects' illness (cocaine addiction): the Attention Network Task (ANT) (Fan et al., 2002) and the Stroop Color-Word Test (Stroop, 1935).
In particular, the ANT was administered to account for effects of global attention. During this task, subjects responded quickly to neutral visual cues in different directions on a computer screen. Accuracy and reaction time were used to measure three factors of attention, including alerting (response readiness), orientating (scanning/selection of information), and executive control (conflict resolution). The Stroop Color-Word Test (Stroop, 1935), a classical executive function task (measuring suppression of automatic response tendencies), was administered to account for effects of executive function. During this task, subjects were asked to name color words printed in either their congruent or incongruent colors; their contrast provides a measure of interference that was examined in the current study. By including these control tasks (i.e., that used neutral, non-drug-associated contexts), we were able to test whether our results were specific to a salient, drug-associated context or could instead be explained by more basic, but related, cognitive functions. These tasks were completed as part of a comprehensive neuropsychological battery described in detail previously (Woicik et al., 2009).

\section{Covariate analysis}

Analyses of covariance (ANCOVAs) were used to control for demographic and other relevant clinical variables that could potentially explain our findings (i.e., continuous variables that showed similar diagnosis $\times D A T 1$ interactions, or categorical variables that showed group differences between the six cell groupings resulting from splitting variables as a function of diagnosis $\times D A T 1$; Table 1 ).

\section{Additional ERP component}

Although we had a priori hypotheses for the LPP, we tested an additional ERP component. Specifically, we probed for potential effects of the N2, which is a negativity that occurs temporally before the LPP and that results from attention to an unexpected stimulus (such as during an oddball paradigm) (Patel and Azzam, 2005). Because our tasks were expected to tap into salience processing rather than general attention processing, we did not expect a diagnosis $\times D A T 1$ interaction for the $\mathrm{N} 2$.

\section{Additional dopaminergic genes}

Although we had a priori hypotheses for the DAT1 gene, we examined two additional DA-related genes that have been associated with addiction and/or inhibitory control. In particular, along with 3'UTR VNTR of the SLC6A3, all subjects were genotyped for the DRD4- and PER2-VNTRs. The DRD4 exon III VNTR has been previously associated with poorer inhibitory control (Congdon et al., 2008); it has also been associated with substance abuse through novelty seeking (Ray et al., 2009), perhaps especially in men (Laucht et al., 2005, 2007). The VNTR polymorphism in intron 3 of PER2 has been associated with cocaine addiction and striatal DA D2 receptor (DRD2) availability (Shumay et al., 2012). For DRD4, after partitioning our sample based on the presence of the 7R-allele, we performed three separate 3 (diagnosis: $\mathrm{CUD}^{+}, \mathrm{CUD}^{-}$, control) $\times 2$ (DRD4 genotype: 7R-allele present vs 7R-allele absent) ANOVAs; for PER2, after partitioning our sample into three genotype groups (high/ high, high/low, and low/low), we performed three separate 3 (diagnosis: $\mathrm{CUD}^{+}, \mathrm{CUD}^{-}$, control $) \times 3($ PER2 genotype: high/high, high/low, and low/low) ANOVAs. The dependent variables in these ANOVAs were the dependent variables that showed significant diagnosis $\times D A T 1$ interactions in the main results.

\section{Results}

\section{Main dependent measures: cocaine versus pleasant}

$L P P s$, ratings, and choice

We analyzed our main dependent measures using 3 (diagnosis: $\mathrm{CUD}^{+}, \mathrm{CUD}^{-}$, control) $\times 2$ (DAT1 genotype: 10R/10R vs 9R/ $10 \mathrm{R}$ or 9R/9R) ANOVAs, with dependent variables that included cocaine $>$ pleasant LPPs, self-reported valence and arousal, and probabilistic and explicit choice (see Table 2 for statistics). Both CUD groups showed greater cocaine $>$ pleasant responsiveness than the healthy controls across all five variables as expected, with diagnosis main effects reaching significance for cocaine $>$ pleasant valence, arousal, and probabilistic choice (Table 2). No group main effects of DAT1 reached significance. Importantly, there 
Table 2. Cocaine $>$ pleasant responsiveness as a function of DAT1 and cocaine urine status

\begin{tabular}{|c|c|c|c|c|}
\hline Variable & Diagnosis main effect & DAT1 main effect & Interaction & Follow-up comparisons \\
\hline Cocaine $>$ pleasant LPPs & $F_{(2,105)}=1.61$ & $F_{(1,105)}=0.03$ & $F_{(2,105)}=4.27^{*}$ & 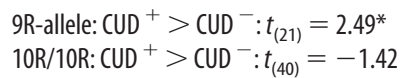 \\
\hline Cocaine $>$ pleasant picture valence & $\begin{array}{l}F_{(2,106)}=13.71^{* * *} \\
\text { CUD }^{+}>\text {CUD }^{-}>\text {control }\end{array}$ & $F_{(1,106)}=0.58$ & $F_{(2,106)}=1.58$ & $\begin{array}{l}\text { 9R-allele: } \mathrm{CUD}^{+}>\mathrm{CUD}^{-}: t_{(23)}=3.20^{* *} \\
\text { 10R/10R: } \mathrm{CUD}^{+}>\mathrm{CUD}^{-}: t_{(43.0)}=0.89\end{array}$ \\
\hline Cocaine $>$ pleasant picture arousal & $\begin{array}{l}F_{(2,106)}=6.31^{* *} \\
\text { Both CUD }>\text { control }\end{array}$ & $F_{(1,106)}=0.04$ & $F_{(2,106)}=0.09$ & $\begin{array}{l}\text { 9R-allele: } \mathrm{CUD}^{+}>\mathrm{CUD}^{-}: t_{(23)}=0.35 \\
\text { 10R/10R: } \mathrm{CUD}^{+}>\mathrm{CUD}^{-}: t_{(43)}=0.14\end{array}$ \\
\hline Cocaine $>$ pleasant probabilistic choice & $\begin{array}{l}F_{(2,99)}=13.07^{* * *} \\
\text { Both CUD }>\text { control }\end{array}$ & $F_{(1,99)}=0.93$ & $F_{(2,99)}=1.76$ & $\begin{array}{l}\text { 9R-allele: } \mathrm{CUD}^{+}>\mathrm{CUD}^{-}: t_{(21)}=2.19^{*} \\
\text { 10R/10R: } \mathrm{CUD}^{+}>\mathrm{CUD}^{-}: t_{(35.8)}=-0.62\end{array}$ \\
\hline Cocaine $>$ pleasant explicit choice & $F_{(2,92)}=2.40$ & $F_{(1,92)}=0.83$ & $F_{(2,92)}=2.45$ & $\begin{array}{l}\text { 9R-allele: } \mathrm{CUD}^{+}>\mathrm{CUD}^{-}: t_{(20)}=1.18 \\
\text { 10R/10R: } \mathrm{CUD}^{+}>\mathrm{CUD}^{-}: t_{(36)}=-1.53\end{array}$ \\
\hline Cocaine $>$ fixation fMRI lateral OFC & $\begin{array}{l}F_{(2,90)}=5.59^{* *} \\
\text { CUD }^{+} \text {and control }>\text { CUD }^{-}\end{array}$ & $F_{(1,90)}=3.62$ & $F_{(2,90)}=4.74^{*}$ & $\begin{array}{l}\text { 9R-allele: } \mathrm{CUD}^{+}>\mathrm{CUD}^{-}: t_{(20)}=2.34^{*} \\
\text { 10R/10R: } \text { CUD }^{+}>\text {CUD }^{-}: t_{(32)}=-0.23\end{array}$ \\
\hline Cocaine $>$ fixation fMRI medial OFC & $F_{(2,90)}=0.96$ & $F_{(1,90)}=2.59$ & $F_{(2,90)}=0.82$ & $\begin{array}{l}\text { 9R-allele: } \mathrm{CUD}^{+}>\mathrm{CUD}^{-}: t_{(20)}=-0.19 \\
\text { 10R/10R: } \mathrm{CUD}^{+}>\mathrm{CUD}^{-}: t_{(32)}=1.32\end{array}$ \\
\hline Cocaine $>$ fixation $\mathrm{fMRl}$ ventral striatum & $F_{(2,90)}=0.98$ & $F_{(1,90)}=0.70$ & $F_{(2,90)}=0.04$ & $\begin{array}{l}\text { 9R-allele: } \mathrm{CUD}^{+}>\mathrm{CUD}^{-}: t_{(20)}=-0.47 \\
\text { 10R/10R: } \mathrm{CUD}^{+}>\mathrm{CUD}^{-}: t_{(32)}=-1.37\end{array}$ \\
\hline Cocaine responsiveness across modalities & $\begin{array}{l}F_{(2,114)}=16.64^{* * *} \\
\text { Both CUD }>\text { control }\end{array}$ & $F_{(1,114)}=0.85$ & $F_{(2,114)}=4.23^{*}$ & 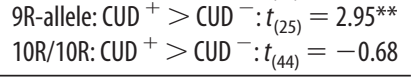 \\
\hline
\end{tabular}

${ }^{*} p<0.05,{ }^{* *} p<0.01,{ }^{* * *} p<0.001$

A
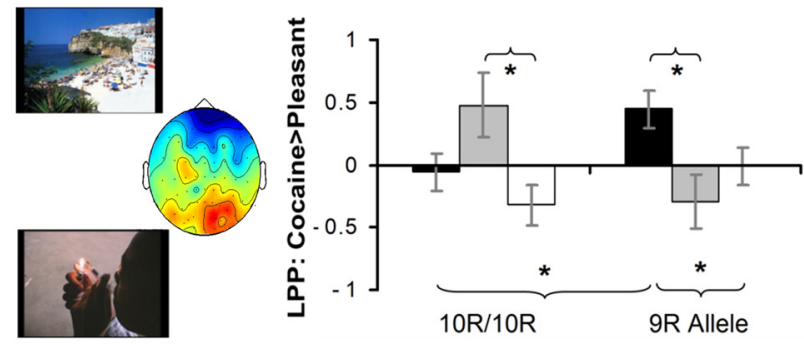

B

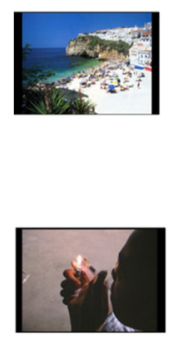

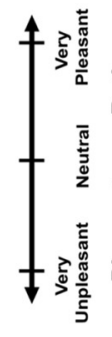

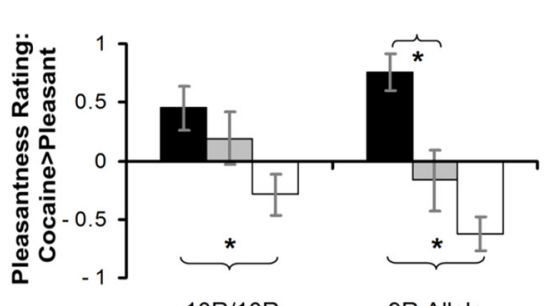

$10 \mathrm{R} / 10 \mathrm{R}$

9R Allele

\section{Urine Positive \\ Urine Negative \\ Healthy Control}

C

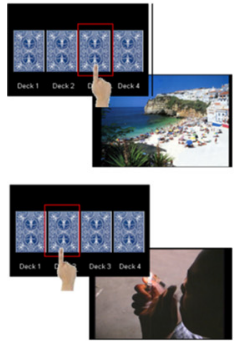

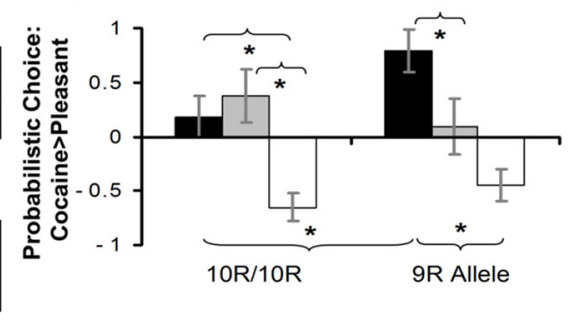
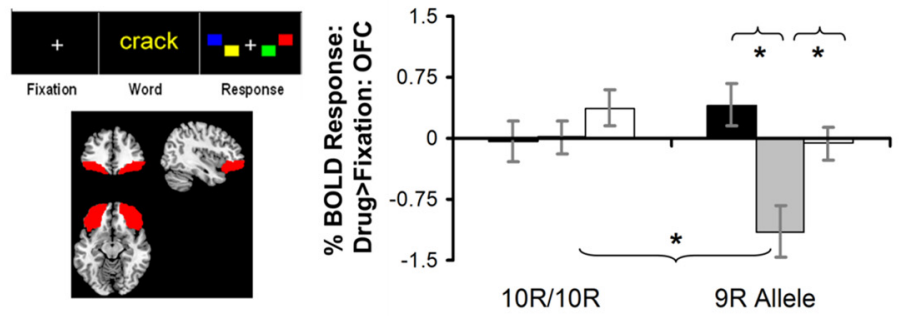

Figure 1. Cocaine $>$ pleasant responsiveness as a function of $D A T 1$ and cocaine urine status as measured by four multimodal dependent variables: $(\boldsymbol{A})$ cocaine $>$ pleasant $L P P s,(B)$ cocaine $>$ pleasant pleasantness ratings, (C) cocaine $>$ pleasant probabilistic choice, and (D) drug $>$ fixation fMRI BOLD response in OFC (image displayed at MNI coordinates $x=37, y=39, z=-12$ ). $\boldsymbol{A}$, $D$, The significant diagnosis $\times$ DAT1 interactions were explained by a urine group difference in the $9 R$-allele subjects, but not in the $10 R / 10 R$ subjects. $B, C$, Post hoc tests revealed that similar urine group differences emerged only in the 9R-allele group. For display purposes, all variables were standardized (mean \pm SD: $0 \pm 1$ ). Error bars are SEM.

was a diagnosis $\times D A T 1$ interaction for the LPPs $(p=0.016)$, explained by a urine group difference $\left(\mathrm{CUD}^{+}>\mathrm{CUD}^{-}\right)$in the 9R-allele carriers but not in the 10R/10R subjects (Fig. 1A). Although the omnibus diagnosis $\times$ DAT1 interactions did not reach significance for the other four variables, in a pattern similar to that of the LPP, and consistent with our hypotheses, valence ratings (Fig. $1 B$ ) and probabilistic choice (Fig. $1 C$ ) showed the expected urine group differences $\left(\mathrm{CUD}^{+}>\mathrm{CUD}^{-}\right)$that emerged only in the 9R-allele subjects.

fMRI response

We also analyzed the three fMRI ROIs (lateral OFC, medial OFC, ventral striatum) with 3 (diagnosis: $\mathrm{CUD}^{+}, \mathrm{CUD}^{-}$, control) $\times 2$ (DAT1 genotype: 10R/10R vs 9R/10R or 9R/9R) ANOVAs, but 
Table 3. Cocaine $>$ neutral responsiveness as a function of DAT1 and cocaine urine status

\begin{tabular}{|c|c|c|c|c|}
\hline Variable & Diagnosis main effect & DAT1 main effect & Interaction & Follow-up comparisons \\
\hline Cocaine $>$ neutral LPPs & $F_{(2,105)}=1.27$ & $F_{(1,105)}=0.00$ & $F_{(2,105)}=0.40$ & $\begin{array}{l}\text { 9R-allele: } \text { CUD }^{+}>\text {CUD }^{-}: t_{(21)}=0.61 \\
\text { 10R/10R: } \text { CUD }^{+}>\text {CUD }^{-}: t_{(40)}=-0.50\end{array}$ \\
\hline Cocaine $>$ neutral picture valence & $\begin{array}{l}F_{(2,106)}=17.93^{* * *} \\
\text { CUD }^{+}>\text {CUD }^{-}>\text {control }\end{array}$ & $F_{(1,106)}=0.10$ & $F_{(2,106)}=1.46$ & $\begin{array}{l}\text { 9R-allele: } \text { CUD }^{+}>\text {CUD }^{-}: t_{(23)}=3.38^{* *} \\
\text { 10R/10R: } \text { CUD }^{+}>\text {CUD }^{-}: t_{(43)}=1.29\end{array}$ \\
\hline Cocaine $>$ neutral picture arousal & $\begin{array}{l}F_{(2,106)}=8.71^{* * *} \\
\text { Both CUD }>\text { control }\end{array}$ & $F_{(1,106)}=0.01$ & $F_{(2,106)}=0.35$ & $\begin{array}{l}\text { 9R-allele: } \text { CUD }^{+}>\text {CUD }^{-}: t_{(23)}=1.04 \\
\text { 10R/10R: } \text { CUD }^{+}>\text {CUD }^{-}: t_{(43)}=0.11\end{array}$ \\
\hline Cocaine $>$ neutral probabilistic choice & $\begin{array}{l}F_{(2,99)}=4.77^{*} \\
\text { Both CUD }>\text { control }\end{array}$ & $F_{(1,99)}=0.22$ & $F_{(2,99)}=2.26$ & $\begin{array}{l}\text { 9R-allele: } \text { CUD }^{+}>\text {CUD }^{-}: t_{(21)}=1.31 \\
\text { 10R/10R: } \text { CUD }^{+}>\text {CUD }^{-}: t_{(37)}=-1.34\end{array}$ \\
\hline Cocaine $>$ neutral explicit choice & $\begin{array}{l}F_{(2,92)}=5.28^{* *} \\
\text { Both CUD }>\text { control }\end{array}$ & $F_{(1,92)}=0.16$ & $F_{(2,92)}=3.75^{*}$ & $\begin{array}{l}\text { 9R-allele: } \mathrm{CUD}^{+}>\mathrm{CUD}^{-}: t_{(20)}=1.69 \\
\text { 10R/10R: } \mathrm{CUD}^{+}>\mathrm{CUD}^{-}: t_{(36)}=-1.62\end{array}$ \\
\hline Cocaine $>$ neutral fMRI lateral OFC & $F_{(2,87)}=0.38$ & $F_{(1,87)}=0.08$ & $F_{(2,87)}=0.58$ & $\begin{array}{l}\text { 9R-allele: } \mathrm{CUD}^{+}>\mathrm{CUD}^{-}: t_{(19)}=-0.80 \\
\text { 10R/10R: } \mathrm{CUD}^{+}>\mathrm{CUD}^{-}: t_{(31)}=0.42\end{array}$ \\
\hline Cocaine $>$ neutral fMRI medial OFC & $F_{(2,87)}=1.34$ & $F_{(1,87)}=0.31$ & $F_{(2,87)}=0.67$ & $\begin{array}{l}\text { 9R-allele: } \mathrm{CUD}^{+}>\mathrm{CUD}^{-}: t_{(19)}=-0.94 \\
\text { 10R/10R: } \mathrm{CUD}^{+}>\mathrm{CUD}^{-}: t_{(31)}=0.13\end{array}$ \\
\hline Cocaine $>$ neutral fMRI ventral striatum & $F_{(2,87)}=0.89$ & $F_{(1,87)}=0.02$ & $F_{(2,87)}=0.01$ & $\begin{array}{l}\text { 9R-allele: } \text { CUD }^{+}>\text {CUD }^{-}: t_{(19)}=-0.34 \\
\text { 10R/10R: } \text { CUD }^{+}>\text {CUD }^{-}: t_{(27.1)}=-0.55\end{array}$ \\
\hline Cocaine responsiveness across modalities & $\begin{array}{l}F_{(2,114)}=12.08^{* * *} \\
\text { Both CUD }>\text { control }\end{array}$ & $F_{(1,114)}=0.02$ & $F_{(2,114)}=1.15$ & $\begin{array}{l}\text { 9R-allele: } \mathrm{CUD}^{+}>\mathrm{CUD}^{-}: t_{(25)}=1.65 \\
\text { 10R/10R: } \mathrm{CUD}^{+}>\mathrm{CUD}^{-}: t_{(44)}=-0.22\end{array}$ \\
\hline
\end{tabular}

${ }^{*} p<0.05,{ }^{* *} p<0.01,{ }^{* * *} p<0.001$.

this time with the drug $>$ fixation $\mathrm{fMRI}$ response as the dependent variables. The lateral OFC ROI showed a main effect of group, no main effect of $D A T 1$, and a diagnosis $\times D A T 1$ interaction $(p=0.011)$. Consistent with results for the other modalities, this interaction was explained by a urine group difference $\left(\mathrm{CUD}^{+}>\mathrm{CUD}^{-}\right)$in the 9R-allele carriers but not in the $10 \mathrm{R} /$ $10 \mathrm{R}$ subjects (Fig. 1D). The other two ROIs showed no main effects or interactions (Table 2).

\section{Combined modalities}

Here we examined responsiveness to the cocaine cues across modalities. $z$-scores were computed for each of the eight dependent variables (LPPs, valence, arousal, explicit choice, probabilistic choice, fMRI lateral OFC, medial OFC, and ventral striatum), which were then averaged to create a composite index of reactivity. The diagnosis $\times D A T 1$ interaction was significant $(p=$ $0.017)$, as expected driven by a urine group difference $\left(\mathrm{CUD}^{+}>\right.$ $\mathrm{CUD}^{-}$) in the $9 \mathrm{R}$-allele carriers but not in the 10R/10R subjects (Table 2). Indeed, a subsequent planned comparison of this composite score showed that the $9 \mathrm{R}$-allele $\mathrm{CUD}^{+}$exhibited higher cocaine-related responsiveness compared with the other five diagnosis-genotype group combinations $\left(t_{(114)}=3.97, p<\right.$ 0.001 ). Even after removing three potential outliers (as identified by a diagnosis $\times$ genotype boxplot on this aggregate variable), both the interaction and the central $\mathrm{CUD}^{+}>\mathrm{CUD}^{-}$comparison remained significant (both $p<0.01$ ). Thus, although the 9R-allele $\mathrm{CUD}^{-}$subgroup was relatively small $(N=10)$, our effects were not driven by an extreme outlier in this subgroup.

\section{Main dependent measures: cocaine versus neutral}

Although our primary hypotheses pertained to the cocaine $>$ pleasant contrast, we also analyzed the more commonly reported cocaine $>$ neutral contrast (see Table 3 for statistics). We again used 3 (diagnosis: $\mathrm{CUD}^{+}, \mathrm{CUD}^{-}$, control) $\times 2$ (DAT1 genotype: $10 \mathrm{R} / 10 \mathrm{R}$ vs $9 \mathrm{R} / 10 \mathrm{R}$ or $9 \mathrm{R} / 9 \mathrm{R})$ ANOVAs, for each of the eight dependent measures. Results of these ANOVAs revealed diagnosis main effects for valence, arousal, probabilistic choice, and explicit choice, again such that both CUD groups showed higher cocaine $>$ neutral responsiveness than controls (Table 3). There were again no significant main effects of DAT1. The only diagnosis $\times D A T 1$ interaction to reach significance, including a newly created cocaine $>$ neutral composite variable, was for cocaine $>$ neutral explicit choice ( $p=0.027)$; and even for this variable, the $\mathrm{CUD}^{+}>\mathrm{CUD}^{-}$comparisons did not reach significance (Table 3). Together, compared with results for the cocaine $>$ pleasant contrast, results for the cocaine $>$ neutral contrast generally exhibited similar directionality but were of weaker magnitude, further supporting our a priori decision to focus on the cocaine $>$ pleasant contrast.

\section{Correlations}

To provide additional validity to the results using cocaine urine status, correlation analyses were conducted with measures relevant to abstinence in CUD. Specifically, for the dependent variables that showed significant diagnosis $\times D A T 1$ interactions (cocaine $>$ pleasant LPPs, fMRI drug $>$ fixation OFC response, and the combined score of cocaine responsiveness across modalities), we examined their correlations with (1) cocaine craving (total score) (Tiffany et al., 1993), (2) cocaine withdrawal (total score) (Kampman et al., 1998), (3) current frequency of cocaine use (days per week, last $30 \mathrm{~d}$ ), and (4) duration of current cocaine abstinence (with current frequency of cocaine use and duration of current cocaine abstinence assessed during the clinical interview). These correlations were conducted separately as a function of DAT1 genotype to examine whether correlations differed between 9R-allele carriers and the 10R/10R group, and tests of correlation differences were computed as appropriate. We hypothesized that carriers of a 9R-allele would show higher correlations between cocaine-related responsiveness with craving, withdrawal, current use, and/or abstinence.

Supporting this hypothesis, only in the 9R-allele subjects, the combined cocaine reactivity score (averaged across all eight dependent variables) correlated at the specified $p<0.01$ threshold with greater cocaine craving (9R-allele, $r=0.58, p=0.002 ; 10 \mathrm{R} /$ $10 \mathrm{R}, r=0.34, p=0.021$; although the correlation difference was not significant, $z=1.20, p=0.23$ ) (Fig. $2 A$ ) and fewer days of cocaine abstinence (9R-allele, Spearman $r=-0.62, p=0.001$; $10 \mathrm{R} / 10 \mathrm{R}, r=-0.07, p=0.65$; correlation difference, $z=2.59$, $p=0.015$ ) (Fig. 2B). We observed a similar pattern of effects between cocaine $>$ pleasant LPPs and higher self-reported cocaine craving (9R-allele, $r=0.62, p=0.002 ; 10 \mathrm{R} / 10 \mathrm{R}, r=0.06$, $p=0.68$; correlation difference, $z=2.40, p=0.016)$. No other correlations reached significance at $p<0.01$. 


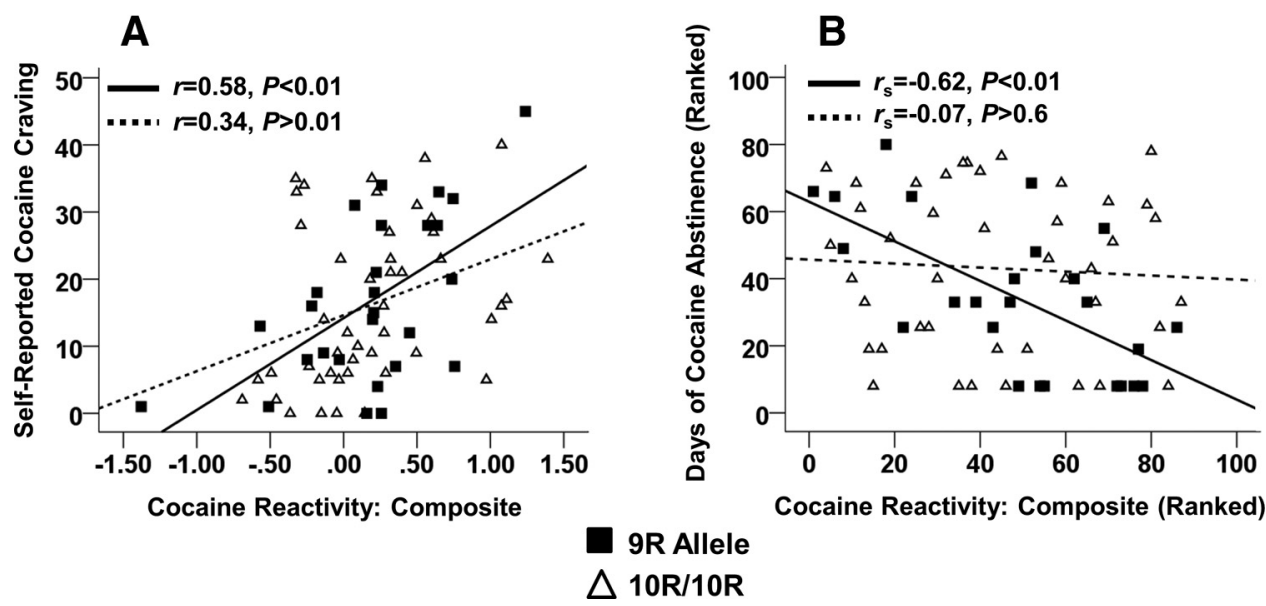

Figure 2. In the 9R-allele subjects, but not in the 10R/10R subjects, a greater response to cocaine cues (indexed by a composite score of cocaine $>$ pleasant LPPs, valence, arousal, explicit choice, and probabilistic choice; and drug $>$ fixation fMRI lateral OFC, medial OFC, and ventral striatum) correlated with ( $\boldsymbol{A}$ ) greater cocaine craving and $(\boldsymbol{B})$ fewer days of current cocaine abstinence. $\boldsymbol{A}$, The abscissa is standardized (mean \pm SD: $0 \pm 1) . B$, Both the abscissa and ordinate are ranked $\left(r_{\mathrm{s}}=\right.$ Spearman correlation).

\section{Control analyses}

Control analyses helped bolster conclusions from our main analyses. (1) Neutral tasks: Diagnosis $\times$ DAT1 interactions were not found when analyzing nonsalient control tasks (Stroop ColorWord Test, $p>0.4$; ANT alerting, $p>0.7$; and ANT conflict, $p>$ $0.5)$; and importantly, on these neutral tasks, there were no urine group differences (as seen in LPPs, pleasantness ratings, probabilistic choice, fMRI, and composite score) in either 9R-allele carriers or the 10R/10R genotype for the ANT subscales (all $p>$ 0.05 ) or Stroop (all $p>0.2$ ). (2) Covariates: Although severity of dependence (Gossop et al., 1992) showed a diagnosis (urine status $) \times D A T 1$ interaction $\left(F_{(2,114)}=4.47, p<0.05\right)$ in CUD, this interaction showed a different pattern of effects than for the cocaine $>$ pleasant reactivity variables (higher severity scores for 9R-allele $\mathrm{CUD}^{-}$); in addition, when covaried in an ANCOVA, this variable did not attenuate the diagnosis $\times D A T 1$ interaction for LPP, fMRI, or composite score (all $p<0.05$ ). Similarly, another potential covariate, smoking history, which is a categorical variable that differed between the diagnosis and DAT1 groups (Table 1), did not attenuate the diagnosis $\times D A T 1$ interaction for LPP, fMRI, or composite score when covaried in an ANCOVA (all $p<0.05$ ). (3) Additional ERP component: The diagnosis $\times$ $D A T 1$ interaction for cocaine $>$ pleasant $\mathrm{N} 2$ did not reach significance as expected ( $p>0.2)$. (4) Additional dopaminergic genes: Diagnosis $\times$ genotype interactions (on cocaine $>$ pleasant LPPs, drug $>$ neutral lateral OFC response, combined cocaine reactivity measure) were not significant for either DRD4 or PER2 (all $p>0.1$.

\section{Discussion}

The dopamine transporter (DAT) is a main regulator of extracellular DA levels in striatum (Gainetdinov et al., 1999), and preclinical studies showed that it modulated conditioning to cocaine (Medvedev et al., 2005). In the current study, we hypothesized and found that DAT1 played a prominent role in modulating drug cue reactivity in human cocaine addiction, with the most pronounced reactivity emerging for carriers of a DAT1 9R-allele who had used cocaine within $72 \mathrm{~h}$ of the study (evidenced by cocaine metabolites in urine). Notably, this pattern of increased reactivity in urine-positive 9R-allele carriers was preserved across multimodal dependent variables (cocaine $>$ pleasant LPPs, drug $>$ fixation fMRI lateral OFC response, and a composite score reflecting these two neuroimaging variables plus selfreports, simulated cocaine choice behavior, and two additional ROIs of high relevance). Correlation analyses with cocaine craving, and with days since last use, showed the association with these abstinence-related measures when continuously measured. Control analyses showed that these results were not driven by covariates and also did not emerge for other DA genes, other global attentional processing or inhibitory control tasks, or for an additional ERP component. We interpret our findings according to the modulatory role of DAT1 on phasic/tonic DA release. In particular, the 9R-allele contributes to a neural phenotype characterized by lowered tonic but increased phasic DA firing (van Dyck et al., 2005), which in turn is associated with increased reward-related responsiveness (Dreher et al., 2009; Forbes et al., 2009). In CUD, this sensitive DA profile may predispose individuals toward increased reactivity to drug cues in dopaminergically innervated brain regions inclusive of the OFC (Franklin et al., 2011).

One explanation of why cocaine responsiveness in the 9Rallele carriers was most powerfully expressed in $\mathrm{CUD}^{+}$is that these individuals may have been in short-term cocaine withdrawal, a state of perturbed DA functioning previously found to be modulated by DAT1. For example, 9R-allele carriers exhibited greater susceptibility to withdrawal-related delirium and seizures in alcoholism (Sander et al., 1997), cocaine-induced paranoia in cocaine addiction (Gelernter et al., 1994), and psychosis (lasting for at least 1 month after discontinuation of use) in methamphetamine addiction (Ujike et al., 2003). Previous studies have indicated that CUD in both short-term and longer-term withdrawal exhibit decreased striatal DA activity (Volkow et al., 1997), including decreases in nonstimulated DA release (Martinez et al., 2009). Considering that this dysregulated DA state might be accentuated in CUD 9R-allele carriers (because of reduced tonic DA activity associated with this allele), and that low tonic DA levels are expected to enhance phasic DA cell firing in response to conditioned cues (Wanat et al., 2009), it indeed follows that these subjects showed heightened sensitivity to drug cues especially while possibly experiencing acute withdrawal (i.e., when tonic DA levels were ostensibly reduced above and beyond the influence of the DAT1 9R-allele). Similar logic was put forth to explain the ability of a DA agonist, small-dose oral methylphenidate 
(which elevates tonic DA levels), to attenuate phasic DA responses to conditioned drug cues in CUD (Volkow et al., 2010). In addition to withdrawal, another potential mechanism underlying our urine status effects may have involved drug priming (i.e., because $\mathrm{CUD}^{+}$, although not acutely intoxicated during the study, self-administered cocaine within $72 \mathrm{~h}$ of the study). Similarly to withdrawal, drug priming leads to increased craving and drug-taking (Donny et al., 2004; Mahoney et al., 2007) that is possibly undergirded by the OFC (in concert with other interconnected regions) (Schmidt et al., 2005). Although the mechanisms underlying our urine status effects therefore remain to be clarified in future studies (i.e., whether withdrawal or priming mainly drive our effects), urine status itself is important for addiction research insofar as it predicts poorer treatment outcome (Poling et al., 2007; Ahmadi et al., 2009; García-Fernández et al., 2011).

Our results have important implications for theorizing about the DAT1 polymorphism. First, our results help inform previous studies suggesting that $9 \mathrm{R}$ carriers may be more sensitive to an environmental challenge (in the current study, short-term abstinence). For example, 9R-allele carriers with attention deficit/hyperactivity disorder showed a stronger correlation between low childhood maternal warmth and increased conduct and emotional problems later in life than non-9R-allele carriers (SonugaBarke et al., 2009). The 9R-allele was also associated with an increased lifetime risk of post-traumatic stress disorder (Chang et al., 2012), indicative of intransigent sensitivity to a distressing experience. Second, although the presence of the 9R-allele has been suggested to reduce the need for novelty and reward by external stimuli (Sabol et al., 1999), our data suggest the opposite conclusion when such individuals have recently used cocaine. To further test this gene $\times$ abstinence hypothesis, future studies can expose addicted individuals to drug cues while experimentally controlling the length of current drug abstinence (e.g., before vs after a laboratory-supervised dose of cocaine in individuals then prospectively monitored for abstinence). More broadly, potentially interesting new studies can be undertaken to test the hypothesis of satiation versus deprivation even beyond drug addiction, extending into other psychopathologies with possible dopaminergic underpinnings that are similarly characterized by excessive reward seeking and impaired inhibition (e.g., obesity, pathological gambling).

Limitations of this study include the following: (1) because the same pictures were used for all picture tasks, repeated exposure to the pictures may have reduced participants' responsiveness to the images. Indeed, because the ERP recordings were administered first, we cannot rule out the possibility that null interaction effects for the other dependent measures was the result of habituation. Future studies could use different image sets for different tasks; here, the goal was consistency of stimuli across pictureviewing modalities. (2) Because the fMRI task did not include pleasant stimuli (and used words instead of pictures), future studies could integrate pleasant stimuli into an fMRI picture cuereactivity task. This design would also allow for follow-up on the comparably high cocaine $>$ pleasant LPP responsiveness in the urine-negative 10R/10R subjects (e.g., does it replicate with fMRI when the comparison is with pleasant stimuli?). (3) As alluded to above, the mechanisms underlying positive cocaine urine screens remain to be clarified, including dissociating withdrawal from priming. In addition, acute withdrawal per se needs to be dissociated from the stress associated with cocaine discontinuation. Future studies could assess whether carriers of the 9R-allele also show enhanced reactivity while undergoing stress that is independent from withdrawal. (4) Current sample size constraints did not allow for data partitioning by gender or ethnicity. In light of previous studies that have uncovered a significant relationship between 3'-UTR VNTR genotype and DAT density in the striatum for whites but not for blacks (Shumay et al., 2011), future studies of this kind could recruit equal numbers of individuals from both races. Another future recruitment goal should be to include more 9R-allele carriers with drug-negative urines and/or longer current abstinence periods, as the size of this subgroup was relatively small $(N=10)$. Although a notable strength of our approach is that our central $\mathrm{CUD}^{+}>\mathrm{CUD}^{-}$contrast in 9Rallele subjects was observed across multiple methodological approaches, and although boxplots did not reveal any large outliers that could potentially drive our findings, results with these 9Rallele CUD ${ }^{-}$should be interpreted with some caution until larger sample sizes are accrued for this subgroup. It could also be interesting to recruit homozygote carriers of the 9R/9R genotype, which were scarce in our sample $(N=8$ across all available subjects). Recruitment of more 9R/9R subjects would be interesting in light of other research that has observed diminished response in the 9R/9R genotype to amphetamine in healthy adults (Lott et al., 2005) and methylphenidate in children with attention deficit hyperactivity disorder (Stein et al., 2005); there is also a seeming contradiction between these studies that suggests blunted responsiveness to DA agonists in 9R/9R subjects (Lott et al., 2005; Stein et al., 2005) and another study suggesting heightened responsiveness to methylphenidate in 9R-allele carriers with binge eating disorder (Davis et al., 2007), which indeed merits further investigation.

In conclusion, results of this study help to elucidate the DAT gene's modulation of behavioral and neural responses to drug cues in addiction, suggesting that such responsiveness depends not only on the trait (gene) but also the state (abstinence) of the individual. Identifying such a specific, well-defined phenotype has the potential to illuminate mechanistic, biologically informed pathways of risk for psychopathology (Sweitzer et al., 2012). Because sensitivity to drug cues is associated with a more severe addiction phenotype (Volkow et al., 2006), cocaine-addicted 9Rallele carriers could possibly benefit from additional therapeutic intervention to help regulate reactivity to drug-associated stimuli, especially during the early stages of treatment, enabling more appropriate and efficient allocation of scarce clinical resources and improved clinical outcomes. In particular, this subgroup of addicted individuals could be targeted for specific treatments and/or medications based on their genetic profiles (an emerging field of study subsumed under the name "pharmacogenetics") (Haile et al., 2009), which has shown initial promise in moderating the effects of naltrexone on drinking behavior (Anton et al., 2012) and cue-reactivity (Schacht et al., 2012) in alcohol dependence.

\section{References}

Ahmadi J, Kampman KM, Oslin DM, Pettinati HM, Dackis C, Sparkman T (2009) Predictors of treatment outcome in outpatient cocaine and alcohol dependence treatment. Am J Addict 18:81-86. CrossRef Medline

Ahmed SH (2010) Validation crisis in animal models of drug addiction: beyond non-disordered drug use toward drug addiction. Neurosci Biobehav Rev 35:172-184. CrossRef Medline

Anton RF, Voronin KK, Randall PK, Myrick H, Tiffany A (2012) Naltrexone modification of drinking effects in a subacute treatment and Bar-Lab Paradigm: influence of OPRM1 and dopamine transporter (SLC6A3) genes. Alcohol Clin Exp Res 36:2000-2007. CrossRef Medline

Berridge KC (2007) The debate over dopamine's role in reward: the case for incentive salience. Psychopharmacology 191:391-431. CrossRef Medline

Brody AL, Mandelkern MA, Olmstead RE, Scheibal D, Hahn E, Shiraga S, Zamora-Paja E, Farahi J, Saxena S, London ED, McCracken JT (2006) 
Gene variants of brain dopamine pathways and smoking-induced dopamine release in the ventral caudate/nucleus accumbens. Arch Gen Psychiatry 63:808-816. CrossRef Medline

Chang SC, Koenen KC, Galea S, Aiello AE, Soliven R, Wildman DE, Uddin M (2012) Molecular variation at the SLC6A3 locus predicts lifetime risk of PTSD in the Detroit Neighborhood Health Study. PLoS One 7:e39184. CrossRef Medline

Congdon E, Lesch KP, Canli T (2008) Analysis of DRD4 and DAT polymorphisms and behavioral inhibition in healthy adults: implications for impulsivity. Am J Med Genet B Neuropsychiatr Genet 147B:27-32. CrossRef Medline

Davis C, Levitan RD, Kaplan AS, Carter J, Reid C, Curtis C, Patte K, Kennedy JL (2007) Dopamine transporter gene (DAT1) associated with appetite suppression to methylphenidate in a case-control study of binge eating disorder. Neuropsychopharmacology 32:2199-2206. CrossRef Medline

Donny EC, Bigelow GE, Walsh SL (2004) Assessing the initiation of cocaine self-administration in humans during abstinence: effects of dose, alternative reinforcement, and priming. Psychopharmacology (Berl) 172:316-323. CrossRef Medline

Dreher JC, Kohn P, Kolachana B, Weinberger DR, Berman KF (2009) Variation in dopamine genes influences responsivity of the human reward system. Proc Natl Acad Sci U S A 106:617-622. CrossRef Medline

Erblich J, Lerman C, Self DW, Diaz GA, Bovbjerg DH (2004) Stress-induced cigarette craving: effects of the DRD2 TaqI RFLP and SLC6A3 VNTR polymorphisms. Pharmacogenomics J 4:102-109. CrossRef Medline

Erblich J, Lerman C, Self DW, Diaz GA, Bovbjerg DH (2005) Effects of dopamine D2 receptor (DRD2) and transporter (SLC6A3) polymorphisms on smoking cue-induced cigarette craving among AfricanAmerican smokers. Mol Psychiatry 10:407-414. CrossRef Medline

Fan J, McCandliss BD, Sommer T, Raz A, Posner MI (2002) Testing the efficiency and independence of attentional networks. J Cogn Neurosci 14:340 -347. CrossRef Medline

First MB, Spitzer RL, Gibbon M, Williams J (1996) Williams J. Structured Clinical Interview for DSM-IV Axis I disorders-patient edition (SCIDI/P, Version 2.0). New York: Biometrics Research Department, New York State Psychiatric Institute.

Forbes EE, Brown SM, Kimak M, Ferrell RE, Manuck SB, Hariri AR (2009) Genetic variation in components of dopamine neurotransmission impacts ventral striatal reactivity associated with impulsivity. Mol Psychiatry 14:60-70. CrossRef Medline

Franklin TR, Wang Z, Li Y, Suh JJ, Goldman M, Lohoff FW, Cruz J, Hazan R, Jens W, Detre JA, Berrettini W, O’Brien CP, Childress AR (2011) Dopamine transporter genotype modulation of neural responses to smoking cues: confirmation in a new cohort. Addict Biol 16:308-322. CrossRef Medline

Gainetdinov RR, Jones SR, Caron MG (1999) Functional hyperdopaminergia in dopamine transporter knock-out mice. Biol Psychiatry 46:303-311. CrossRef Medline

García-Fernández G, Secades-Villa R, García-Rodríguez O, Alvarez-López H, Sánchez-Hervás E, Fernández-Hermida JR, Fernández-Artamendi S (2011) Individual characteristics and response to Contingency Management treatment for cocaine addiction. Psicothema 23:114-118. Medline

Gelernter J, Kranzler HR, Satel SL, Rao PA (1994) Genetic association between dopamine transporter protein alleles and cocaine-induced paranoia. Neuropsychopharmacology 11:195-200. CrossRef Medline

Goldstein RZ, Volkow ND (2011) Dysfunction of the prefrontal cortex in addiction: neuroimaging findings and clinical implications. Nat Rev Neurosci 12:652-669. CrossRef Medline

Goldstein RZ, Alia-Klein N, Tomasi D, Honorio Carrillo JH, Maloney T, Woicik PA, Wang R, Telang F, Volkow ND (2009) Anterior cingulate cortex hypoactivations to an emotionally salient task in cocaine addiction. Proc Natl Acad Sci U S A 106:9453-9458. CrossRef Medline

Gossop M, Griffiths P, Powis B, Strang J (1992) Severity of dependence and route of administration of heroin, cocaine and amphetamines. Br J Addict 87:1527-1536. CrossRef Medline

Haber SN, Knutson B (2010) The reward circuit: linking primate anatomy and human imaging. Neuropsychopharmacology 35:4-26. CrossRef Medline

Haile CN, Kosten TR, Kosten TA (2009) Pharmacogenetic treatments for drug addiction: cocaine, amphetamine and methamphetamine. Am J Drug Alcohol Abuse 35:161-177. CrossRef Medline

Hajcak G, MacNamara A, Olvet DM (2010) Event-related potentials, emo- tion, and emotion regulation: an integrative review. Dev Neuropsychol 35:129-155. CrossRef Medline

Horvitz JC (2000) Mesolimbocortical and nigrostriatal dopamine responses to salient non-reward events. Neuroscience 96:651-656. CrossRef Medline

Kampman KM, Volpicelli JR, McGinnis DE, Alterman AI, Weinrieb RM, D'Angelo L, Epperson LE (1998) Reliability and validity of the Cocaine Selective Severity Assessment. Addict Behav 23:449-461. CrossRef Medline

Konova AB, Moeller SJ, Tomasi D, Parvaz MA, Alia-Klein N, Volkow ND, Goldstein RZ (2012) Structural and behavioral correlates of abnormal encoding of money value in the sensorimotor striatum in cocaine addiction. Eur J Neurosci 36:2979-2988. CrossRef Medline

Lang PJ, Bradley MM, Cuthbert BN (2008) International Affective Picture System (IAPS): affective ratings of pictures and instruction manual. Technical Report A-8. Gainesville, FL: University of Florida.

Laucht M, Becker K, El-Faddagh M, Hohm E, Schmidt MH (2005) Association of the DRD4 exon III polymorphism with smoking in fifteen-yearolds: a mediating role for novelty seeking? J Am Acad Child Adolesc Psychiatry 44:477-484. CrossRef Medline

Laucht M, Becker K, Blomeyer D, Schmidt MH (2007) Novelty seeking involved in mediating the association between the dopamine D4 receptor gene exon III polymorphism and heavy drinking in male adolescents: results from a high-risk community sample. Biol Psychiatry 61:87-92. CrossRef Medline

Lee JH, Garwood M, Menon R, Adriany G, Andersen P, Truwit CL, Uðurbil K (1995) High contrast and fast three-dimensional magnetic resonance imaging at high fields. Magn Reson Med 34:308-312. CrossRef Medline

Lott DC, Kim SJ, Cook EH Jr, de Wit H (2005) Dopamine transporter gene associated with diminished subjective response to amphetamine. Neuropsychopharmacology 30:602-609. CrossRef Medline

Mahoney JJ 3rd, Kalechstein AD, De La Garza R 2nd, Newton TF (2007) A qualitative and quantitative review of cocaine-induced craving: the phenomenon of priming. Prog Neuropsychopharmacol Biol Psychiatry 31: 593-599. CrossRef Medline

Martinez D, Greene K, Broft A, Kumar D, Liu F, Narendran R, Slifstein M, Van Heertum R, Kleber HD (2009) Lower level of endogenous dopamine in patients with cocaine dependence: findings from PET imaging of $D(2) / D(3)$ receptors following acute dopamine depletion. Am J Psychiatry 166:1170-1177. CrossRef Medline

McLellan AT, Kushner H, Metzger D, Peters R, Smith I, Grissom G, Pettinati H, Argeriou M (1992) The fifth edition of the Addiction Severity Index. J Subst Abuse Treat 9:199-213. CrossRef Medline

Medvedev IO, Gainetdinov RR, Sotnikova TD, Bohn LM, Caron MG, Dykstra LA (2005) Characterization of conditioned place preference to cocaine in congenic dopamine transporter knockout female mice. Psychopharmacology (Berl) 180:408-413. CrossRef Medline

Moeller SJ, Maloney T, Parvaz MA, Dunning JP, Alia-Klein N, Woicik PA, Hajcak G, Telang F, Wang GJ, Volkow ND, Goldstein RZ (2009) Enhanced choice for viewing cocaine pictures in cocaine addiction. Biol Psychiatry 66:169-176. CrossRef Medline

Moeller SJ, Maloney T, Parvaz MA, Alia-Klein N, Woicik PA, Telang F, Wang GJ, Volkow ND, Goldstein RZ (2010) Impaired insight in cocaine addiction: laboratory evidence and effects on cocaine-seeking behaviour. Brain 133:1484-1493. CrossRef Medline

Moeller SJ, Hajcak G, Parvaz MA, Dunning JP, Volkow ND, Goldstein RZ (2012) Psychophysiological prediction of choice: relevance to insight and drug addiction. Brain 135:3481-3494. CrossRef Medline

Moeller SJ, Beebe-Wang N, Woicik PA, Konova AB, Maloney T, Goldstein RZ (2013) Choice to view cocaine images predicts concurrent and prospective drug use in cocaine addiction. Drug Alcohol Depend 130:178-185. CrossRef Medline

Padoa-Schioppa C, Cai X (2011) The orbitofrontal cortex and the computation of subjective value: consolidated concepts and new perspectives. Ann N Y Acad Sci 1239:130-137. CrossRef Medline

Parvaz MA, Maloney T, Moeller SJ, Woicik PA, Alia-Klein N, Telang F, Wang GJ, Squires NK, Volkow ND, Goldstein RZ (2012) Sensitivity to monetary reward is most severely compromised in recently abstaining cocaine addicted individuals: a cross-sectional ERP study. Psychiatry Res 203:75-82. CrossRef Medline

Patel SH, Azzam PN (2005) Characterization of N200 and P300: selected 
studies of the Event-Related Potential. Int J Med Sci 2:147-154. CrossRef Medline

Poling J, Kosten TR, Sofuoglu M (2007) Treatment outcome predictors for cocaine dependence. Am J Drug Alcohol Abuse 33:191-206. CrossRef Medline

Ray LA, Bryan A, Mackillop J, McGeary J, Hesterberg K, Hutchison KE (2009) The dopamine D receptor (DRD4) gene exon III polymorphism, problematic alcohol use and novelty seeking: direct and mediated genetic effects. Addict Biol 14:238-244. CrossRef Medline

Sabol SZ, Nelson ML, Fisher C, Gunzerath L, Brody CL, Hu S, Sirota LA, Marcus SE, Greenberg BD, Lucas FR 4th, Benjamin J, Murphy DL, Hamer DH (1999) A genetic association for cigarette smoking behavior. Health Psychol 18:7-13. CrossRef Medline

Sander T, Harms H, Podschus J, Finckh U, Nickel B, Rolfs A, Rommelspacher H, Schmidt LG (1997) Allelic association of a dopamine transporter gene polymorphism in alcohol dependence with withdrawal seizures or delirium. Biol Psychiatry 41:299-304. CrossRef Medline

Schacht JP, Anton RF, Voronin KE, Randall PK, Li X, Henderson S, Myrick H (2013) Interacting effects of naltrexone and OPRM1 and DAT1 variation on the neural response to alcohol cues. Neuropsychopharmacology 38: 414-422. CrossRef Medline

Schmidt HD, Anderson SM, Famous KR, Kumaresan V, Pierce RC (2005) Anatomy and pharmacology of cocaine priming-induced reinstatement of drug seeking. Eur J Pharmacol 526:65-76. CrossRef Medline

Schultz W (2010) Dopamine signals for reward value and risk: basic and recent data. Behav Brain Funct 6:24. CrossRef Medline

Shumay E, Chen J, Fowler JS, Volkow ND (2011) Genotype and ancestry modulate brain's DAT availability in healthy humans. PLoS One 6:e22754. CrossRef Medline

Shumay E, Fowler JS, Wang GJ, Logan J, Alia-Klein N, Goldstein RZ, Maloney T, Wong C, Volkow ND (2012) Repeat variation in the human PER2 gene as a new genetic marker associated with cocaine addiction and brain dopamine D2 receptor availability. Transl Psychiatry 2:e86. CrossRef Medline

Sonuga-Barke EJ, Oades RD, Psychogiou L, Chen W, Franke B, Buitelaar J, Banaschewski T, Ebstein RP, Gil M, Anney R, Miranda A, Roeyers H, Rothenberger A, Sergeant J, Steinhausen HC, Thompson M, Asherson P, Faraone SV (2009) Dopamine and serotonin transporter genotypes moderate sensitivity to maternal expressed emotion: the case of conduct and emotional problems in attention deficit/hyperactivity disorder. J Child Psychol Psychiatry 50:1052-1063. CrossRef Medline

Stein MA, Waldman ID, Sarampote CS, Seymour KE, Robb AS, Conlon C, Kim SJ, Cook EH (2005) Dopamine transporter genotype and methylphenidate dose response in children with ADHD. Neuropsychopharmacology 30:1374-1382. CrossRef Medline

Stroop JR (1935) Studies of interference in serial verbal reactions. J Exp Psychol 18:643-662. CrossRef
Sweitzer MM, Donny EC, Hariri AR (2012) Imaging genetics and the neurobiological basis of individual differences in vulnerability to addiction. Drug Alcohol Depend 123 [Suppl 1]:S59-S71.

Tiffany ST, Singleton E, Haertzen CA, Henningfield JE (1993) The development of a cocaine craving questionnaire. Drug Alcohol Depend 34:19-28. CrossRef Medline

Ujike H, Harano M, Inada T, Yamada M, Komiyama T, Sekine Y, Sora I, Iyo M, Katsu T, Nomura A, Nakata K, Ozaki N (2003) Nine- or fewer repeat alleles in VNTR polymorphism of the dopamine transporter gene is a strong risk factor for prolonged methamphetamine psychosis. Pharmacogenomics J 3:242-247. CrossRef Medline

van Dyck CH, Malison RT, Jacobsen LK, Seibyl JP, Staley JK, Laruelle M, Baldwin RM, Innis RB, Gelernter J (2005) Increased dopamine transporter availability associated with the 9-repeat allele of the SLC6A3 gene. J Nucl Med 46:745-751. Medline

Volkow ND, Wang GJ, Fowler JS, Logan J, Gatley SJ, Hitzemann R, Chen AD, Dewey SL, Pappas N (1997) Decreased striatal dopaminergic responsiveness in detoxified cocaine-dependent subjects. Nature 386:830-833. CrossRef Medline

Volkow ND, Wang GJ, Telang F, Fowler JS, Logan J, Childress AR, Jayne M, Ma Y, Wong C (2006) Cocaine cues and dopamine in dorsal striatum: mechanism of craving in cocaine addiction. J Neurosci 26:6583-6588. CrossRef Medline

Volkow ND, Wang GJ, Tomasi D, Telang F, Fowler JS, Pradhan K, Jayne M, Logan J, Goldstein RZ, Alia-Klein N, Wong C (2010) Methylphenidate attenuates limbic brain inhibition after cocaine-cues exposure in cocaine abusers. PLoS One 5:e11509. CrossRef Medline

Volkow ND, Wang GJ, Fowler JS, Tomasi D, Telang F (2011) Addiction: beyond dopamine reward circuitry. Proc Natl Acad Sci U S A 108:1503715042. CrossRef Medline

Wager TD, Keller MC, Lacey SC, Jonides J (2005) Increased sensitivity in neuroimaging analyses using robust regression. Neuroimage 26:99-113. CrossRef Medline

Wanat MJ, Willuhn I, Clark JJ, Phillips PE (2009) Phasic dopamine release in appetitive behaviors and drug addiction. Curr Drug Abuse Rev 2:195213. CrossRef Medline

Wetherill RR, Jagannathan K, Lohoff FW, Ehrman R, O’Brien CP, Childress AR, Franklin TR (2012) Neural correlates of attentional bias for smoking cues: modulation by variance in the dopamine transporter gene. Addict Biol Advance online publication. Retrieved October 12, 2012. doi: 10.1111/j.1369-1600.2012.00507.x. CrossRef Medline

Woicik PA, Moeller SJ, Alia-Klein N, Maloney T, Lukasik TM, Yeliosof O, Wang GJ, Volkow ND, Goldstein RZ (2009) The neuropsychology of cocaine addiction: recent cocaine use masks impairment. Neuropsychopharmacology 34:1112-1122. CrossRef Medline 